Meta

Journal des traducteurs

Translators' Journal

\title{
The Shifting of the Demonstrative Determiner in French and Dutch in Parallel Corpora: From Translation Mechanisms to Structural Differences
}

\author{
Gudrun Vanderbauwhede, Piet Desmet et Peter Lauwers
}

Volume 56, numéro 2, juin 2011

Les corpus et la recherche en terminologie et en traductologie Corpora and Research in Terminology and Translation Studies

URI : https://id.erudit.org/iderudit/1006186ar

DOI : https://doi.org/10.7202/1006186ar

Aller au sommaire du numéro

Éditeur(s)

Les Presses de l’Université de Montréal

ISSN

0026-0452 (imprimé)

1492-1421 (numérique)

Découvrir la revue

Citer cet article

Vanderbauwhede, G., Desmet, P. \& Lauwers, P. (2011). The Shifting of the Demonstrative Determiner in French and Dutch in Parallel Corpora: From Translation Mechanisms to Structural Differences. Meta, 56(2), 443-464. https://doi.org/10.7202/1006186ar
Résumé de l'article

Le présent article a pour objet les changements intervenant au niveau du déterminant démonstratif dans des traductions en français et en néerlandais (corpus parallèles). Il s'agit d'identifier les différents types de changements intervenant systématiquement dans la traduction, d'en étudier les mécanismes sous-jacents ainsi que les effets sémantiques. L'étude a été réalisée à l'aide d'un sous-corpus équilibré du Dutch Parallel Corpus, ce qui permet d'analyser les deux directions (français-néerlandais et néerlandais-français). Dans ce corpus, $50 \%$ des déterminants démonstratifs sont traduits par un démonstratif dans le texte traduit (dans les deux directions). Dans $20 \%$ des cas, le démonstratif est traduit par l'article défini et vice versa, tandis que $30 \%$ sont traduits par un autre élément grammatical (p. ex., déterminant indéfini, adverbe, pronom personnel) et vice versa. L'étude du corpus parallèle montre que les changements de traduction au niveau du démonstratif en français et en néerlandais peuvent être reliés à trois mécanismes différents : (1) choix du traducteur en relation avec des universaux de la traduction au niveau du syntagme nominal (omissions, additions et reformulations du syntagme nominal), (2) manifestations spécifiques d'universaux de la traduction à l'intérieur du syntagme nominal (explicitation et implicitation syntagmatique et paradigmatique entraînant des changements au niveau du démonstratif) et (3) divergences structurelles entre les systèmes du déterminant démonstratif en français et en néerlandais (expressions figées et différences sémantiques). L'analyse montre l'utilité d'une étude de corpus parallèle détaillée, qui fait une distinction claire entre des changements à différents niveaux et qui rend compte des différents types de traduction du déterminant démonstratif dans différentes langues. Pour ce faire, plusieurs types d'explication issus de différents domaines (tels que l'étude de la traduction et la linguistique contrastive) doivent être pris en considération.
Ce document est protégé par la loi sur le droit d'auteur. L’utilisation des services d’Érudit (y compris la reproduction) est assujettie à sa politique d'utilisation que vous pouvez consulter en ligne.

https://apropos.erudit.org/fr/usagers/politique-dutilisation/ 


\title{
The Shifting of the Demonstrative Determiner in French and Dutch in Parallel Corpora: From Translation Mechanisms to Structural Differences
}

\author{
GUDRUN VANDERBAUWHEDE \\ Katholieke Universiteit Leuven, Leuven, Belgium \\ gudrun.vanderbauwhede@arts.kuleuven.be \\ PIET DESMET \\ Katholieke Universiteit Leuven, Leuven, Belgium \\ piet.desmet@kuleuven-kortrijk.be \\ PETER LAUWERS \\ Universiteit Gent, Ghent, Belgium \\ Katholieke Universiteit Leuven, Leuven, Belgium \\ peter.lauwers@ugent.be
}

\section{RÉSUMÉ}

Le présent article a pour objet les changements intervenant au niveau du déterminant démonstratif dans des traductions en français et en néerlandais (corpus parallèles). II s'agit d'identifier les différents types de changements intervenant systématiquement dans la traduction, d'en étudier les mécanismes sous-jacents ainsi que les effets sémantiques. L'étude a été réalisée à l'aide d'un sous-corpus équilibré du Dutch Parallel Corpus, ce qui permet d'analyser les deux directions (français-néerlandais et néerlandais-français). Dans ce corpus, $50 \%$ des déterminants démonstratifs sont traduits par un démonstratif dans le texte traduit (dans les deux directions). Dans $20 \%$ des cas, le démonstratif est traduit par l'article défini et vice versa, tandis que $30 \%$ sont traduits par un autre élément grammatical (p. ex., déterminant indéfini, adverbe, pronom personnel) et vice versa. L'étude du corpus parallèle montre que les changements de traduction au niveau du démonstratif en français et en néerlandais peuvent être reliés à trois mécanismes différents: (1) choix du traducteur en relation avec des universaux de la traduction au niveau du syntagme nominal (omissions, additions et reformulations du syntagme nominal), (2) manifestations spécifiques d'universaux de la traduction à l'intérieur du syntagme nominal (explicitation et implicitation syntagmatique et paradigmatique entraînant des changements au niveau du démonstratif) et (3) divergences structurelles entre les systèmes du déterminant démonstratif en français et en néerlandais (expressions figées et différences sémantiques). L'analyse montre l'utilité d'une étude de corpus parallèle détaillée, qui fait une distinction claire entre des changements à différents niveaux et qui rend compte des différents types de traduction du déterminant démonstratif dans différentes langues. Pour ce faire, plusieurs types d'explication issus de différents domaines (tels que l'étude de la traduction et la linguistique contrastive) doivent être pris en considération.

\section{ABSTRACT}

This paper focuses on translational shifts with respect to the demonstrative determiner in French and Dutch in parallel corpora. The paper aims to identify the types of translation shifts that occur systematically, and to explore the underlying mechanisms and semantic effects of this process. For this purpose, a well-balanced sub-corpus of the Dutch Parallel Corpus is used, making it possible to analyze both directions (French - 
Dutch and Dutch - French). In this corpus, $50 \%$ of the demonstrative determiners are translated by a demonstrative in the target text (in both directions). In $20 \%$ of the cases, the demonstrative is translated by a definite article, or vice versa, while $30 \%$ are translated by another grammatical element (e.g., indefinite determiner, adverb, personal pronoun) or vice versa. The parallel corpus study reveals that translational shifts with respect to French and Dutch demonstratives can be attributed to three different mechanisms: (1) translator preference related to translation universals at the level of the noun phrase (omissions, additions and reformulations of the noun phrase), (2) specific manifestations of translation universals within the noun phrase (syntagmatic and paradigmatic explicitation and implicitation involving demonstrative shifting) and (3) structural divergences between the French and Dutch demonstrative determiner systems (fixed expressions and semantic differences). This analysis demonstrates the usefulness of a detailed parallel corpus study, which clearly distinguishes between changes occurring at different levels, in accounting for divergent translations of the demonstrative determiner in different languages. To this end, several types of explanation drawn from various fields (such as translation studies and contrastive linguistics), must be considered.

\section{MOTS-CLÉS/KEYWORDS}

déterminants démonstratifs, français/néerlandais, corpus parallèles, changements au niveau du démonstratif, mécanismes de traduction

demonstrative determiners, French/Dutch, parallel corpora, demonstrative shifting, translation mechanisms

\section{Introduction}

This paper focuses on translational shifts with respect to the demonstrative determiner in French and Dutch in parallel corpora. So far, three similar studies have been conducted for other language pairs. In her corpus study, Jonasson (1998) found that in one third of the cases, French demonstrative determiners were translated by definite articles in Swedish, and that a French demonstrative with a recognitial function was generally translated by a definite article in Swedish. Whittaker (2004) found that noun phrases featuring a demonstrative were considerably more frequent in the French target texts than in the Norwegian source texts. Whittaker argues that this finding may be explained by the explicitation hypothesis, a well-known translation mechanism (Baker 1993; Blum-Kulka 1986; Chesterman 2001; Klaudy 1993; Pym 2005; Toury 2001) defined as follows by Blum-Kulka (1986):

The process of interpretation performed by the translator on the source text might lead to a TL text which is more redundant than the SL text. This redundancy can be expressed by a rise in the level of cohesive explicitness in the TL text. This argument may be stated as "explicitation hypothesis," which postulates an observed cohesive explicitness from SL to TL texts regardless of the increase traceable to differences between the two linguistic and textual systems involved. It follows that explicitation is viewed here as inherent in the process of translation (Blum-Kulka 1986: 19).

Finally, the results presented by Goethals (2007), whose corpus contains more Dutch demonstratives translated by Spanish definite articles than vice versa, suggest that the Dutch demonstrative pronoun is more grammaticalized than its Spanish equivalent and that this divergence cannot be attributed to translation mechanisms or translator preference alone. The present corpus study focuses on the translation of demonstrative determiners in French and Dutch parallel corpora. 
Table 1 summarizes the different forms of the demonstrative determiner in both languages under consideration, while table 2 presents the forms of the definite article:

TABLE 1

Forms of the demonstrative determiner in French and Dutch

\begin{tabular}{|l|c|c|c|c|c|c|}
\cline { 2 - 6 } \multicolumn{1}{c|}{} & \multicolumn{3}{c|}{ Singular } & \multicolumn{3}{c|}{ Plural } \\
\cline { 2 - 7 } \multicolumn{1}{c|}{} & Masculine & Feminine & Neuter & Masculine & Feminine & Neuter \\
\hline French & $c e$, cet & cette & $/$ & \multicolumn{2}{c|}{ ces } & $/$ \\
\hline Dutch & \multicolumn{2}{c|}{ deze, die } & dit, dat & \multicolumn{3}{c}{ deze, die } \\
\hline
\end{tabular}

TABLE 2

Forms of the definite article in French and Dutch

\begin{tabular}{|l|c|c|c|c|c|c|}
\cline { 2 - 7 } \multicolumn{1}{c|}{} & \multicolumn{3}{c|}{ Singular } & \multicolumn{3}{c|}{ Plural } \\
\cline { 2 - 7 } \multicolumn{1}{c|}{} & Masculine & Feminine & Neuter & Masculine & Feminine & Neuter \\
\hline French & le & la & $/$ & \multicolumn{2}{c|}{ les } & $/$ \\
\hline Dutch & \multicolumn{2}{|c}{$d e$} & het & \multicolumn{3}{c}{ de } \\
\hline
\end{tabular}

The present study aims to identify the types of translation shifts that occur systematically and to explore the underlying mechanisms and semantic effects of this demonstrative shifting. In this respect, complete omissions, as in example (1), ${ }^{1}$ would seem to result from translator preference as an inherent element of the translation process. In example (2), on the other hand, demonstrative shifting seems to be driven by paradigmatic implicitation of the head noun in the target text (from Doubistes to team), whereas in example (3), it seems impossible to attribute the shift from a demonstrative determiner in the French source text to a definite article in the Dutch target text to mechanisms inherent in the translation process. Possible linguistic, structural differences between the French and Dutch demonstrative determiner systems will therefore be studied in greater detail (see also Vanderbauwhede to appear).

(1) Je m'intéressais plus au basket et à la politique qu'aux filles, à ce moment-là. Ik had meer oog voor basket en politiek dan voor meisjes.

(2) Les Doubistes ont également acquis Fousseni Diawara (Saint-Étienne). Les deux hommes sont prêtés.

Dat team verzekerde zich eveneens via een huurovereenkomst ook van de diensten van Fousseni Diawara (Saint-Etienne).

(3) Plusieurs de nos clients ne le savent pas encore, mais Fortis Private Banking a développé au cours de ces dernières années un pôle de spécialisation particulièrement performant dans le domaine des crédits patrimoniaux sur mesure.

Een aantal van onze cliënten is er zich misschien nog niet bewust van, maar Fortis Private Banking heeft de voorbije jaren een gespecialiseerde en performante pool voor patrimoniumkredieten op maat ontwikkeld.

The paper is organized as follows: first, the corpus used is presented. Second, the basic findings and the main research question are summarized. The next section of the paper attempts to account for the process of demonstrative shifting at three levels, namely translator preference related to translation universals at the level of the noun phrase, specific manifestations of translation universals within the noun phrase, and structural differences between the French and Dutch demonstrative 
determiner systems. The paper concludes with a detailed overview of demonstrative shifting in the corpus.

\section{Corpus}

For the present analysis, the Dutch Parallel Corpus, a 10-million-word parallel corpus comprising texts in Dutch, English and French with Dutch as a pivotal language (Paulussen, Macken et al. 2006), was used. The DPC project was coordinated by the University of Leuven Kortrijk Campus and University College Ghent, and was funded by the Dutch Language Union (Nederlandse Taalunie) within the framework of the STEVIN programme (Essential Speech and Language Technology Resources), which promotes research in Dutch language and speech technology.

The Dutch Parallel Corpus is a well-balanced corpus designed to include the widest possible range of written texts. Text types range from literary prose to nonfiction material, such as essays or newspaper, business, technical and policy texts. Quality control mechanisms include manual verification, spot checks and automatic control procedures. Another advantage of this corpus is its sentence alignment (Trushkina, Macken et al. 2008).

For this analysis, we use a well-balanced sub-corpus of the DPC, including 50,000 French words and 50,000 Dutch words in the source text and their translation into Dutch and French respectively. The entire sub-corpus of 200,000 words consists of $40 \%$ essayistic texts, $40 \%$ newspaper texts (news reports, comments) and $20 \%$ informative texts (external communication). These different text types ensure a varied sub-corpus. However, in this paper, we will not focus on possible divergences between the three text types.

TABLE 3

The sub-corpus based on the Dutch Parallel Corpus

\begin{tabular}{|c|c|c|c|c|c|c|c|c|}
\hline \multicolumn{4}{|c|}{ Source language } & \multicolumn{4}{|c|}{ Target language } & \\
\hline & essays & $\begin{array}{c}\text { newspaper } \\
\text { texts }\end{array}$ & $\begin{array}{c}\text { informative } \\
\text { texts }\end{array}$ & & essays & $\begin{array}{c}\text { newspaper } \\
\text { texts }\end{array}$ & $\begin{array}{c}\text { informative } \\
\text { texts }\end{array}$ & \\
\hline FR & 20,000 & 20,000 & 10,000 & $\mathrm{DU}$ & 20,000 & 20,000 & 10,000 & 100,000 \\
\hline DU & 20,000 & 20,000 & 10,000 & FR & 20,000 & 20,000 & 10,000 & 100,000 \\
\hline & 40,000 & 40,000 & 20,000 & & 40,000 & 40,000 & 20,000 & 200,000 \\
\hline
\end{tabular}

\section{Basic findings and research questions}

Table 4 and Table 5 give an overview of the translation of the French and Dutch demonstrative determiner in the sub-corpus:

TABLE 4

The translation of the demonstrative determiner in the DPC sub-corpus (French SL - Dutch TL)

\begin{tabular}{|c|c|c|c|}
\hline French SL & Dutch TL & Number & $\%$ \\
\hline Demonstrative & Demonstrative & 236 & $43.95 \%$ \\
\hline Demonstrative & Other structure & 111 & $20.67 \%$ \\
\hline Demonstrative & Definite article & 96 & $17.88 \%$ \\
\hline Other structure & Demonstrative & 73 & $13.59 \%$ \\
\hline Definite article & Demonstrative & 21 & $3.91 \%$ \\
\hline \multicolumn{2}{|l}{} & $\mathbf{5 3 7}$ & $\mathbf{1 0 0 \%}$ \\
\cline { 3 - 4 }
\end{tabular}


TABLE 5

The translation of the demonstrative determiner in the DPC sub-corpus (Dutch SL - French TL)

\begin{tabular}{|c|c|c|c|}
\hline Dutch SL & French TL & Number & $\%$ \\
\hline Demonstrative & Demonstrative & 294 & $52.78 \%$ \\
\hline Demonstrative & Other structure & 63 & $11.31 \%$ \\
\hline Demonstrative & Definite article & 42 & $7.54 \%$ \\
\hline Other structure & Demonstrative & 98 & $17.59 \%$ \\
\hline Definite article & Demonstrative & 60 & $10.77 \%$ \\
\cline { 2 - 4 } & & $\mathbf{5 5 7}$ & $\mathbf{1 0 0 \%}$ \\
\cline { 3 - 4 }
\end{tabular}

First, overall, we find that $48.36 \%$ of the demonstrative determiners are translated by a demonstrative in the target text, and that this is the case in both directions (French - Dutch and Dutch - French). In 20.02\% of the cases, a demonstrative determiner is translated by a definite article, or vice versa, and $31.58 \%$ of the demonstratives are translated by another word category (e.g., by an indefinite determiner, an adverb, a personal pronoun) or vice versa (i.e., another structure is translated by a demonstrative determiner). The divergences suggested by these quantitative results confirm the findings of a prior analysis (Vanderbauwhede 2007) based on a subcorpus of another parallel corpus, i.e., the Namur Corpus (Paulussen 1999). In this sub-corpus (10\% of the entire Namur Corpus), no less than $33 \%$ of the French and Dutch demonstratives were translated by a definite article or vice versa.

Second, there are several differences between French and Dutch. In the French SL corpus (443 demonstratives), the demonstrative determiner is more frequent than in the Dutch SL corpus (399 demonstratives). This is also the case for the French TL corpus (452 demonstratives) with respect to the Dutch TL corpus (330 demonstratives). Moreover, regardless of the direction between SL and TL, French demonstratives are much more frequently translated by the Dutch definite article than vice versa (i.e., 2.48/1), while French demonstratives are more commonly translated by another structure than vice versa (i.e., 1,54/1):

TABLE 6

Relative frequency of the demonstrative - definite article and demonstrative - other structure pairs in the DPC sub-corpus

\begin{tabular}{|l|c|c|}
\cline { 2 - 3 } \multicolumn{1}{c|}{} & demonstrative - definite article & demonstrative - other structure \\
\hline French - Dutch & 156 & 209 \\
\hline Dutch - French & 63 & 136 \\
\cline { 2 - 3 } & $\mathbf{2 . 4 8 / 1}$ & $=\mathbf{1 . 5 4} / \mathbf{1}$ \\
\hline
\end{tabular}

As the demonstrative determiner is underused in the Dutch TL corpus (330 demonstratives) compared with the French SL corpus (443 demonstratives) and overused in the French TL corpus (452 demonstratives) compared with the Dutch SL corpus (399 demonstratives), we can conclude from a methodological perspective that not only the French and the Dutch SL corpus, but also the French and the Dutch TL corpus can be considered as validated comparable corpora.

These important quantitative differences raise the following question: are the translational shifts of the French and the Dutch demonstrative determiner in the corpus due to translator preference related to translation universals at the level of the 
noun phrase (3.1.), to specific manifestations of translation universals within the noun phrase (3.2.), or to major structural differences between the French and Dutch demonstrative determiner systems (3.3.)? These possible explanations will now be examined in greater detail at the three different levels.

\section{Explanations at three different levels}

All divergent translations with respect to the demonstrative were collected and classified into three categories, namely divergences at the level of the noun phrase, at the level of the head noun and its modifiers, and at the level of the determiner. In what follows, it will be shown that this subdivision at three levels allows us to account for demonstrative shifting in the corpus.

\subsection{Translator preference related to translation universals at the level of the noun phrase}

Table 7, Table 8 and Table 9 show that changes at the level of the noun phrase are mainly due to either the complete omission or addition of the noun phrase, or its reformulation (i.e., reformulation of the whole utterance, adverbs, demonstrative pronouns and personal pronouns):

\section{TABLE 7}

Overview of changes at the level of the noun phrase (French SL - Dutch TL)

\begin{tabular}{|c|c|c|c|c|}
\hline French SL & Dutch TL & Total & $\begin{array}{l}\text { Changes to } \\
\text { the entire NP }\end{array}$ & $\%$ \\
\hline \multirow[t]{4}{*}{ Demonstrative } & Demonstrative & 236 & 28 & $11.86 \%$ \\
\hline & Reformulation & & 18 & \\
\hline & - Demonstrative pronoun ${ }^{2}$ & & 5 & \\
\hline & + Demonstrative pronoun & & 5 & \\
\hline \multirow[t]{5}{*}{ Demonstrative } & Other structure & 111 & 67 & $60.36 \%$ \\
\hline & Reformulation & & 26 & \\
\hline & Adverb & & 20 & \\
\hline & Omission & & 17 & \\
\hline & Personal pronoun & & 4 & \\
\hline \multirow[t]{2}{*}{ Demonstrative } & Definite article & 96 & 17 & $17.71 \%$ \\
\hline & Reformulation & & 17 & \\
\hline Other structure & Demonstrative & 73 & 50 & $67.49 \%$ \\
\hline Reformulation & & & 25 & \\
\hline Omission & & & 12 & \\
\hline Personal pronoun & & & 9 & \\
\hline Adverb & & & 4 & \\
\hline Definite article & Demonstrative & 21 & 3 & $14.29 \%$ \\
\hline Reformulation & & & 3 & \\
\hline & & 537 & 165 & $30.73 \%$ \\
\hline
\end{tabular}


TABLE 8

Overview of changes at the level of the entire noun phrase (Dutch SL - French TL)

\begin{tabular}{|c|c|c|c|c|}
\hline Dutch SL & French TL & Total & $\begin{array}{l}\text { Changes to } \\
\text { the entire NP }\end{array}$ & $\%$ \\
\hline \multirow[t]{4}{*}{ Demonstrative } & Demonstrative & 294 & 32 & $10.88 \%$ \\
\hline & - Demonstrative pronoun & & 16 & \\
\hline & Reformulation & & 14 & \\
\hline & + Demonstrative pronoun & & 2 & \\
\hline \multirow[t]{5}{*}{ Demonstrative } & Other structure & 63 & 45 & $71.43 \%$ \\
\hline & Omission & & 15 & \\
\hline & Personal pronoun & & 11 & \\
\hline & Reformulation & & 10 & \\
\hline & Adverb & & 9 & \\
\hline \multirow[t]{2}{*}{ Demonstrative } & Definite article & 42 & 6 & $14.29 \%$ \\
\hline & Reformulation & & 6 & \\
\hline Other structure & Demonstrative & 98 & 66 & $67.35 \%$ \\
\hline Adverb & & & 33 & \\
\hline Omission & & & 13 & \\
\hline Reformulation & & & 13 & \\
\hline Personal pronoun & & & 7 & \\
\hline Definite article & Demonstrative & 60 & 4 & $6.67 \%$ \\
\hline Reformulation & & & 4 & \\
\hline 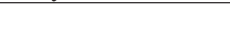 & & 557 & 153 & $27.47 \%$ \\
\hline
\end{tabular}

TABLE 9

Overview of differences at the level of the entire noun phrase in the DPC sub-corpus

\begin{tabular}{|l|c|c|c|}
\hline Changes to the entire NP & $\begin{array}{c}\text { Number } \\
\text { French SL } \\
\text { Dutch TL }\end{array}$ & $\begin{array}{c}\text { Number } \\
\text { Dutch SL } \\
\text { French TL }\end{array}$ & $\begin{array}{c}\text { Number } \\
\text { French SL - Dutch TL } \\
\text { Dutch SL - French TL }\end{array}$ \\
\hline Reformulation & 89 & 47 & 136 \\
\hline Adverb & 24 & 42 & 66 \\
\hline Omission / addition & 29 & 28 & 57 \\
\hline Personal pronoun & 13 & 18 & 31 \\
\hline Demonstrative pronoun & 10 & 18 & 28 \\
\hline
\end{tabular}

In the corpus, omissions or reformulations of the noun phrase with a demonstrative determiner in the target text are almost exclusively due to translator preference related to the broader context of translation universals, as a NP-to-NP translation would also have been possible. This is illustrated in the examples below.

Example (4) is an example of complete omission (32 cases): à ce moment-là has not been translated in the target text, but the translator could have translated this accessory phrase by the prepositional phrase op dat moment or by the adverb toen in Dutch. The temporal adverb toen does not contain any demonstrative determiner, but expresses the same type of anteriority as op dat moment and à ce moment-là.

(4) Je m'intéressais plus au basket et à la politique qu'aux filles, à ce moment-là. Ik had meer oog voor basket en politiek dan voor meisjes.

Conversely, example (5) is an example of addition or explicitation (25 cases), a well-known phenomenon in translation studies (cf. Introduction). As the translator 
did not have to add van deze biografie after non-expression of the referent in the preceding sentences, the cohesive explicitness in the target text is clearly a personal preference inherent to the translation process:

(5) Mais comme l'indique à juste titre l'auteur, la tolérance ne peut être assimilée à l'indifférence et encore moins à l'absence de principes ou à la pauvreté idéologique. Maar zoals de auteur van deze biografie terecht opmerkt, is verdraagzaamheid niet gelijk te stellen met onverschilligheid, laat staan met beginselloosheid of ideologische leegheid.

Example (6) shows a simple reformulation (135 cases): pour s'engager dans cette voie is translated as initiatieven ter zake in Dutch (= des initiatives à ce propos / en la matière), which does not contain a demonstrative determiner, but it could also be literally translated as om deze weg in te slaan (with a demonstrative determiner). The translation by initiatieven ter zake is a stylistic choice on the translator's part.

(6) Pour s'engager dans cette voie, des festivités sportives telles le marathon entre Lille et Lens baptisé La Route du Louvre, et demain L’Anneau bleu, parade nautique artistique et citoyenne sur les rivières et canaux qui traversent le territoire d'un hypothétique district, s'efforcent, sous l'impulsion du Conseil de développement attaché à L.M.C.U., de faire tisser aux gens les liens d'un territoire distendu.

Initiatieven ter zake zijn de marathon Rijsel-Lens la Route du Louvre, en de geplande artistieke parade l'Anneau bleu op de rivieren en kanalen die door het toekomstige district lopen. De Conseil de Développement die afhangt van LMCU gaf daartoe de aanzet.

Example (7) is an example of reformulation by a relative phrase. The noun phrases een hersteltermijn and die termijn are replaced by the relative pronoun qui in the target language. However, both constructions are possible in French and Dutch:

(7) Er valt een hersteltermijn te respecteren en die termijn bedraagt zes maanden. Il y a un délai à respecter, qui est de six mois.

In some cases, the entire noun phrase with a demonstrative determiner is translated by a personal pronoun or vice versa (31 cases) or by a demonstrative pronoun or vice versa ( 28 cases). This finding can be explained by two factors: first, explicitation of the personal pronoun or the demonstrative pronoun using a noun phrase with a demonstrative determiner in the target text (cf. explicitation hypothesis), as in examples (8) and (9), and second, the decision of the translator to replace the noun phrase by a personal or demonstrative pronoun in the broader context of the preceding text (cf. implicitation), as in examples (10) and (11):

(8) Zo heb ik in het spreken van het Berbers een vorm van neokoloniaal verzet gezien die in Marokko zelf al een tijdje is afgelopen, maar bij deze generatie nog zijn weerslag kent. Afgehouden door jarenlange negering vanuit het centrum van Marokko - de Rif had geen hoge prioriteit - gaat men de taal koesteren.

C'est ce qui m'a conduit à voir dans la volonté de parler berbère la résurgence d'un colonialisme disparu au Maroc même depuis un certain temps mais qui a encore des retombées sur la génération actuelle. Issue d'un Rif trop longtemps tenu pour quantité négligeable par la métropole marocaine, cette génération s'éprend de sa langue. 
(9) Tijdens de ontwikkeling van diabetische nefropathie is er een therapeutisch venster vóór de stijging van het serumcreatinine. Dit wordt gedomineerd door hyperglycemie, hypertensie en hyperlipidemie.

Pendant le développement d'une néphropathie diabétique, il y a une fenêtre thérapeutique avant l'augmentation de la créatinine sérique. Ce stade est dominé par une hyperglycémie, une hypertension et une hyperlipidémie.

(10) Mais «la mise en évidence de l'activation de l’amygdale lors de la présentation d'expressions de joie suggère que cette structure serait impliquée dans d'autres aspects de la réponse émotionnelle, notamment les émotions associées à la récompense», lit-on dans un article publié en 2003 dans PSN.

Maar "het feit dat de amygdala wordt geactiveerd bij presentatie van gezichten die vreugde uitstralen, wijst erop dat ze ook een rol zou spelen bij andere aspecten van de emotionele respons, met name bij emoties die samenhangen met een beloning," staat te lezen in een artikel dat in 2003 werd gepubliceerd in PSN.

(11) OC22 bracht Alain Indria op het spoor van een Italiaans bedrijf, waarvan Indria de naam niet wil vrijgeven. Dat bedrijf innoveerde op vraag van Indria met een nieuw "bag-in-box"systeem, waarbij de koeling al in de doos zit.

OC22 a mis Alain Indria en contact avec une société italienne, dont il préfère taire le nom. À sa demande, celle-ci a conçu un nouveau système de caisse-outre ("bagin-box"), où le dispositif de refroidissement des boissons se trouve déjà dans la boîte.

However, when a noun phrase with a demonstrative determiner is replaced by an adverb or vice versa (66 cases), this is not always due to translator preference. In (12), for instance, the French - Dutch translator could have translated the French prepositional phrase including a demonstrative determiner (sur ce point) by a Dutch prepositional phrase with a demonstrative determiner (op dit punt) or by a pronominal adverb in Dutch (daarover). In (13), in contrast, the Dutch - French translator had to translate the Dutch pronominal adverb (hierover) as a prepositional phrase in French (à ce sujet), since these kinds of adverbs (e.g., hiermee, daartussenin, daartegen, daarvoor) do not exist in French.

(12) 48\% des managers interrogés dans l'étude s'accordent d'ailleurs sur ce point, laissant supposer que les domaines d'incompétence dont parle Peter sont plutôt de cet ordre.

Van de managers die voor de studie werden ondervraagd, is $48 \%$ het daarover eens. Dat laat veronderstellen dat de incompetentie waar Peter het over heeft, meestal in verband te brengen is met "soft skills."

(13) Meer informatie hierover vindt $\mathrm{u}$ op de website van de FOD Sociale Zekerheid Si vous souhaitez obtenir davantage d'informations à ce sujet, consultez le site internet du SPF Sécurité sociale.

In summary, examples (4) to (13) show that in cases of omission or reformulation of the entire noun phrase, the French or Dutch demonstrative determiner could also be expressed differently in the target language. In these cases, the French or Dutch demonstrative determiner does not seem to be structurally untranslatable.

In contrast, in the following examples, the translation shifts with respect to the demonstrative determiner are not a matter of translator preference. This is especially the case when another definite determiner (particularly the definite article) is involved in the target text. 
In example (14), for instance, the addition of the adjective interne causes a determiner shift from the demonstrative determiner in the source text (cette note) to the definite article in the target text (de interne nota). While the addition of the adjective can be ascribed to translator preference and to translation universals, it also has an important impact on the determiner in the noun phrase (demonstrative determiner or definite article).

(14) J'avais à mes côtés d'excellents collaborateurs, qui avaient préparé une longue note sur la nécessité de la dévaluation - Jacques Van Yperseele (qui fut responsable pour la presse d'André Vlerick, l'ancien ministre des Finances, avant de devenir chef de cabinet du roi Baudouin puis d'Albert II) et Fons Verplaetse, mon chef de cabinet. Cette note fut distribuée à quelques ministres, les plus importants et, à la demande de Jean Gol, à Robert Henrion, ancien ministre des Finances, éminence grise du PRL à l'époque et ancien gouverneur de la Société Générale.

Ik was omringd door uitstekende medewerkers, die een omstandige nota hadden opgesteld over de noodzaak van een devaluatie. Het ging om Jacques Van Yperseele, die eerder perschef was van minister André Vlerick en later kabinetschef zou worden van koning Boudewijn en nadien Albert II Een andere sterkhouder was mijn eigen kabinetschef Fons Verplaetse. De interne nota bezorgden we aan enkele ministers en op vraag van Gol ook aan Robert Henrion, een gewezen minister van Financiën, éminence grise bij de Franstalige liberalen en oud-gouverneur van de Generale Maatschappij.

In examples (15) and (16), there is only a determiner shift. The definite article and the demonstrative determiner seem interchangeable in these sentences, but it should be determined whether any trends can be identified in the distribution differences between the French and Dutch demonstrative determiner systems, and whether these cases reflect a preference for either the demonstrative or the definite article.

(15) Vous vous souvenez de ces images qui ont fait le tour du monde, où l'on vous voit en train de vous doper?

Herinnert $u$ zich nog de beelden die de wereld rond zijn gegaan en waarop te zien is hoe $u$ zich dopeert?

(16) Omgaan met de steeds grotere verscheidenheid van mensen en situaties in de stad moet daarom de bron worden van een nieuw identiteitsgevoel, een identiteit op basis van stedelijkheid, op basis van de omgang met diversiteit.

Gérer cette diversité croissante de personnes et de situations dans la ville doit être source d'un nouveau sentiment d'identité, une identité sur la base de l'urbanité, sur la base de l'apprentissage de la diversité.

\subsection{Specific manifestations of translation universals within the noun phrase}

Table 10, table 11 and table 12 show that syntagmatic and paradigmatic explicitation and implicitation within the target noun phrase may be mechanisms underlying determiner shifting in our corpus, particularly when the demonstrative determiner is translated by a definite article and vice versa. In these cases, syntagmatic and paradigmatic changes at the level of the head noun and its modifiers seem to be involved: 
TABLE 10

Overview of changes within the noun phrase (French SL - Dutch TL)

\begin{tabular}{|c|c|c|c|c|}
\hline French SL & Dutch TL & Total & Changes within the NP & $\%$ \\
\hline \multirow[t]{9}{*}{ Demonstrative } & Demonstrative & 236 & 13 & $5.51 \%$ \\
\hline & Syntagmatic changes: & & 6 & \\
\hline & - Modifier & & 3 & \\
\hline & + Plural & & 2 & \\
\hline & + Modifier & & 1 & \\
\hline & Semantic changes: & & 7 & \\
\hline & Synonym & & 4 & \\
\hline & Hyponym & & 2 & \\
\hline & Hyperonym & & 1 & \\
\hline \multirow[t]{8}{*}{ Demonstrative } & Other structure & 111 & 16 & $14.41 \%$ \\
\hline & Syntagmatic changes: & & 3 & \\
\hline & - Modifier & & 2 & \\
\hline & + Modifier & & 1 & \\
\hline & Paradigmatic changes: & & 13 & \\
\hline & Hyponym & & 11 & \\
\hline & Hyperonym & & 1 & \\
\hline & Synonym & & 1 & \\
\hline \multirow[t]{8}{*}{ Demonstrative } & Definite article & 96 & 27 & $28.13 \%$ \\
\hline & Syntagmatic changes: & & 14 & \\
\hline & + Modifier & & 10 & \\
\hline & - Modifier & & 3 & \\
\hline & - Plural & & 1 & \\
\hline & Paradigmatic changes: & & 13 & \\
\hline & Hyponym & & 7 & \\
\hline & Synonym & & 6 & \\
\hline Other structure & Demonstrative & 73 & 4 & $5.48 \%$ \\
\hline Syntagmatic changes: & & & 1 & \\
\hline+ Modifier & & & 1 & \\
\hline Paradigmatic changes: & & & 3 & \\
\hline Synonym & & & 3 & \\
\hline Definite article & Demonstrative & 21 & 2 & $9.52 \%$ \\
\hline Syntagmatic changes: & & & 1 & \\
\hline+ Plural & & & 1 & \\
\hline Paradigmatic changes: & & & 1 & \\
\hline Hyponym & & & 1 & \\
\hline & & 537 & 62 & $11.55 \%$ \\
\hline
\end{tabular}


TABLE 11

Overview of changes within the noun phrase (Dutch SL - French TL)

\begin{tabular}{|c|c|c|c|c|}
\hline Dutch SL & French TL & Total & Changes within the NP & $\%$ \\
\hline \multirow[t]{8}{*}{ Demonstrative } & Demonstrative & 294 & 11 & $3.74 \%$ \\
\hline & Syntagmatic changes: & & 7 & \\
\hline & - Modifier & & 4 & \\
\hline & + Modifier & & 2 & \\
\hline & + Plural & & 1 & \\
\hline & Paradigmatic changes: & & 4 & \\
\hline & Synonym & & 3 & \\
\hline & Hyperonym & & 1 & \\
\hline Demonstrative & Other structure & 63 & 0 & $0 \%$ \\
\hline \multirow[t]{6}{*}{ Demonstrative } & Definite article & 42 & 9 & $21.43 \%$ \\
\hline & Syntagmatic changes: & & 8 & \\
\hline & + Modifier & & 7 & \\
\hline & - Modifier & & 1 & \\
\hline & Paradigmatic changes: & & 1 & \\
\hline & Hyponym & & 1 & \\
\hline Other structure & Demonstrative & 98 & 2 & $2.04 \%$ \\
\hline Syntagmatic changes: & & & 1 & \\
\hline - Modifier & & & 1 & \\
\hline Paradigmatic changes: & & & 1 & \\
\hline Hyponym & & & 1 & \\
\hline Definite article & Demonstrative & 60 & 12 & $20 \%$ \\
\hline Syntagmatic changes: & & & 6 & \\
\hline+ Modifier & & & 5 & \\
\hline - Modifier & & & 1 & \\
\hline Paradigmatic changes: & & & 6 & \\
\hline Hyponym & & & 5 & \\
\hline Hyperonym & & & 1 & \\
\hline & & 557 & 34 & $6.10 \%$ \\
\hline
\end{tabular}

TABLE 12

Overview of changes within the noun phrase in the DPC sub-corpus

\begin{tabular}{|c|c|c|c|}
\hline Changes within the NP & $\begin{array}{c}\text { Number } \\
\text { French SL } \\
\text { Dutch TL }\end{array}$ & $\begin{array}{c}\text { Number } \\
\text { Dutch SL } \\
\text { French TL }\end{array}$ & $\begin{array}{c}\text { Number } \\
\text { French SL - Dutch TL } \\
\text { Dutch SL - French TL }\end{array}$ \\
\hline Syntagmatic changes: & 25 & 22 & 47 \\
\hline + / - Modifier & 21 & 21 & 42 \\
\hline + / - Plural & 4 & 1 & 5 \\
\hline Paradigmatic changes: & 37 & 12 & 49 \\
\hline Hyponym / hyperonym & 23 & 9 & 31 \\
\hline Synonym & 14 & 3 & $\mathbf{9 6}$ \\
\hline
\end{tabular}

A first example of explicitation in the target text is the use of lexical expansion (syntagmatic change). This process of making the noun phrase longer, clearer or more complex is responsible for a large number of the instances of demonstrative shifting in the corpus (Chesterman 2001; Toury 2001). The insertion of an adjective (e.g., Rijselse) or a right-hand modifier (e.g., van Lombardsijde, de Rodenbach), for 
instance, causes a determiner shift, i.e., the demonstrative determiner is replaced by a definite article in the target text (17 cases). The type specifications of the nouns and its modifiers (Langacker 1991) in the target text are sufficiently rich to accept the definite article instead of the demonstrative determiner:

(17) Bruxelles peut certainement s'inspirer de cet exemple pour se développer et dynamiser l'ensemble de son hinterland économique.

Voor zijn economische ontwikkeling en de samenwerking met zijn hinterland kan Brussel zonder twijfel profijt trekken uit het Rijselse model.

(18) Cet énorme camp, qui existe toujours, comptait au moins deux mille soldats et candidats officiers et sous-officiers.

De militaire basis van Lombardsijde, die nog altijd bestaat, was een 'fabriek' waar zeker tweeduizend rekruten, kandidaat-officieren en -onderofficieren opgeleid werden.

(19) Een grondig consumentenonderzoek bij die klanten leverde vier merkwaarden op en wees op de noodzaak om het merkbeeld aan te passen aan de eenentwintigste eeuw.

Une étude de marché approfondie réalisée auprès des fans de Rodenbach a permis de distinguer quatre qualités essentielles (lire l'encadré en page de droite) et de se rendre compte de la nécessité d'adapter l'image de la marque au $21^{e}$ siècle.

This determiner shift caused by lexical expansion also occurs in the opposite direction (5 cases): in the following examples, van Europa and specifieke are not translated or used in the target text, which causes the definite article in the source text to shift to the demonstrative determiner in the target text to compensate for the loss of type specification of the modifiers of the nouns in the target text. These cases involve syntagmatic implicitation rather than explicitation.

(20) In het taalmozaïek van Europa worden daarnaast ruim veertig talen erkend onder het Europese Handvest Regionale Minderheidstalen van de Raad van Europa. Et cette mosaïque linguistique se complète encore d'une bonne quarantaine de langues protégées par la Charte européenne des langues régionales ou minoritaires du Conseil de l'Europe.

(21) Ontwerpen en inrichten vergen maatwerk per publieke ruimte, afhankelijk van het huidige gebruik en van de plaats en functie van de specifieke ruimtes in het stedelijke netwerk.

La conception et l'aménagement d'un espace public nécessite à chaque fois du surmesure, en fonction de l'usage actuel, de la place et de la fonction de cet espace dans le réseau urbain.

In the case of hyponyms (paradigmatic change), the emergence of the definite article or the zero article in the target text (French or Dutch translation), rather than the demonstrative determiner, seems to be significant (19 cases). In the following examples, the head nouns bouwsector, amygdala, Appels and Fondation are more strongly specified in the target text than in the source text, where we have secteur, structure, dernier and stichting (despite the presence of the modifier van openbaar nut). In these cases, paradigmatic explicitation of the head noun causes the demonstrative in the source text to be replaced by a definite article or a zero article in the target text to counterbalance the stronger type specification of the noun in the target text. 
(22) La mesure a réellement stimulé ce secteur, selon l'adage bien connu que quand le bâtiment va, tout va.

Die maatregel gaf een flinke stimulans aan de bouwsector en een bevestiging van het gezegde dat als de bouw goed gaat, alles marcheert.

(23) Cette structure a été fort étudiée parce qu'elle est apparue comme l'un des substrats neuroanatomiques essentiels de cette émotion, laquelle résulte en réalité de l'activation de multiples zones.

De amygdala werd echter sterk onderzocht omdat zij een van de essentiële neuroanatomische substraten van die emotie blijkt te zijn. Schrik ontstaat echter door activatie van vele zones.

(24) Grâce à la générosité de ce dernier, le LAAC possède un très bel aperçu de ses œuvres, dont L'animal blessé de 1961-1962, peint sur une souche d'olivier.

Dankzij Appels vrijgevigheid bezit het LAAC een mooi overzicht van zijn werk, waaronder Het gewonde dier (1961-1962), geschilder op een olijfstronk.

(25) Deze stichting van openbaar nut bezit tegenwoordig ongeveer 92 procent van de aandelen van Robert Bosch $\mathrm{GmbH}$.

La Fondation détient à l'heure actuelle environ 92 pour cent des parts de capital de la Robert Bosch GmbH.

This determiner shift also occurs in the opposite direction, when a definite article and a hyponym in the source text are translated by a demonstrative determiner and a hyperonym with less semantic information in the target text $(7$ cases). In the following examples, the type specification of événement and team is less rich than for wereldrecordgebeuren and Doubistes, which has to be counterbalanced by the demonstrative determiner in the target text:

(26) Rita, de hoofdrolspeelster in die spotjes, is dan ook prominent aanwezig op het wereldrecordgebeuren.

Rita, l'actrice qui joue le rôle principal dans ces spots, est aussi très présente à cet événement.

(27) Les Doubistes ont également acquis Fousseni Diawara (Saint-Etienne). Les deux hommes sont prêtés.

Dat team verzekerde zich eveneens via een huurovereenkomst ook van de diensten van Fousseni Diawara (Saint-Etienne).

In summary, syntagmatic and paradigmatic explicitation of the noun phrase in the target text involving different type specifications of the noun and its modifiers may cause the demonstrative determiner in the source text to be replaced by a definite article (or, to a lesser extent, a zero article) in the target text. Conversely, syntagmatic and paradigmatic implicitation of the noun phrase in the target text may cause the definite article in the source text to be replaced by the demonstrative determiner in the target text:

TABLE 13

Syntagmatic and paradigmatic explicitation and implicitation involving demonstrative shifting

\begin{tabular}{|c|c|}
\hline Source text & Target text \\
\hline demonstrative determiner & definite article + explicitation \\
\hline definite article + explicitation & demonstrative determiner \\
\hline
\end{tabular}




\subsection{Structural differences between the French and the Dutch demonstrative determiner}

What happens if we only consider the cases of complete NP - NP correspondence with a determiner shift in the corpus, as in examples (3), (15) and (16)? Is there any other mechanism underlying this process? This question can only be addressed by examining possible structural differences between the French and Dutch demonstrative determiner systems.

Table 14, table 15 and table 16 show that NP changes at the determiner level mostly involve a shift between the demonstrative determiner and the definite article (60\%). In the other corpus instances, the indefinite article, the possessive determiner and the zero article tend to be used. In what follows, we will focus on the shift from the demonstrative determiner to the definite article and vice versa.

TABLE 14

Overview of changes at the determiner level (French SL - Dutch TL)

\begin{tabular}{|c|c|c|c|c|}
\hline French SL & Dutch TL & Total & $\begin{array}{c}\text { Changes at } \\
\text { the determiner level }\end{array}$ & $\%$ \\
\hline Demonstrative & Demonstrative & 236 & I & 1 \\
\hline \multirow[t]{5}{*}{ Demonstrative } & Other structure & 111 & 28 & $5.21 \%$ \\
\hline & Indefinite determiner & & 13 & \\
\hline & Zero article & & 7 & \\
\hline & Beide & & 5 & \\
\hline & Possessive determiner & & 3 & \\
\hline Demonstrative & Definite article & 96 & 52 & $54.17 \%$ \\
\hline Other structure & Demonstrative & 73 & 19 & $26.03 \%$ \\
\hline Indefinite determiner & & & 13 & \\
\hline Possessive determiner & & & 6 & \\
\hline Definite article & Demonstrative & 21 & 16 & 76.19 \\
\hline & & 537 & 115 & $21.42 \%$ \\
\hline
\end{tabular}

TABLE 15

Overview of changes at the determiner level (Dutch SL - French TL)

\begin{tabular}{|c|c|c|c|c|}
\hline Dutch SL & French TL & Total & $\begin{array}{c}\text { Changes at } \\
\text { the determiner level }\end{array}$ & $\%$ \\
\hline Demonstrative & Demonstrative & 294 & 1 & 1 \\
\hline \multirow[t]{5}{*}{ Demonstrative } & Other structure & 63 & 18 & $3.23 \%$ \\
\hline & Indefinite determiner & & 10 & \\
\hline & Possessive determiner & & 6 & \\
\hline & Partitive article & & 1 & \\
\hline & Ce type de & & 1 & \\
\hline Demonstrative & Definite article & 42 & 27 & $64.29 \%$ \\
\hline Other structure & Demonstrative & 98 & 30 & $30.61 \%$ \\
\hline Indefinite determiner & & & 17 & \\
\hline Zero article & & & 9 & \\
\hline Beide & & & 2 & \\
\hline Possessive determiner & & & 1 & \\
\hline Interrogative determiner & & & 1 & \\
\hline Definite article & Demonstrative & 60 & 44 & $73.33 \%$ \\
\hline & & 557 & 119 & $21.36 \%$ \\
\hline
\end{tabular}


TABLE 16

Overview of changes at the determiner level in the DPC sub-corpus

\begin{tabular}{|l|c|c|c|}
\hline $\begin{array}{l}\text { Changes in the use of the demonstrative } \\
\text { at the determiner level }\end{array}$ & $\begin{array}{c}\text { Number } \\
\text { French SL } \\
\text { Dutch TL }\end{array}$ & $\begin{array}{c}\text { Number } \\
\text { Dutch SL } \\
\text { French TL }\end{array}$ & $\begin{array}{c}\text { Number } \\
\text { French SL - Dutch TL } \\
\text { Dutch SL - French TL }\end{array}$ \\
\hline Definite article & 68 & 71 & 139 \\
\hline Indefinite determiner & 26 & 27 & 53 \\
\hline Possessive determiner & 9 & 7 & 16 \\
\hline Zero article & 7 & 9 & 16 \\
\hline Beide & 5 & 2 & 7 \\
\hline Interrogative determiner & 0 & 1 & 1 \\
\hline Partitive article & 0 & 1 & 1 \\
\hline Ce type de & 0 & 1 & 1 \\
\hline & $\mathbf{1 1 5}$ & $\mathbf{1 1 9}$ & $\mathbf{2 3 4}$ \\
\cline { 2 - 4 }
\end{tabular}

Analysis of the corpus instances of complete NP - NP correspondence with a demonstrative shift to the definite article and vice versa reveals that, regardless of the direction between source and target language, significantly more French demonstratives are translated by the Dutch definite article than vice versa (2.23/1). The result reported in table 17 is only slightly lower than the result presented in table 6 (coefficient: 2.48/1):

TABLE 17

Relative frequency of the demonstrative - definite article and demonstrative - other structure pairs in the DPC sub-corpus

\begin{tabular}{|l|c|c|}
\cline { 2 - 3 } \multicolumn{1}{c|}{} & $\begin{array}{c}\text { demonstrative - definite article } \\
\text { all cases }\end{array}$ & $\begin{array}{c}\text { demonstrative - definite article } \\
\text { changes at the determiner level }\end{array}$ \\
\hline French - Dutch & 156 & 96 \\
\hline Dutch - French & 63 & 43 \\
\hline & $=2.48 / 1$ & $2.23 / 1$ \\
\hline
\end{tabular}

A closer look at these data reveals a number of structural differences between the French and Dutch demonstrative determiner systems that cannot be ascribed to the translator preference and translation universals, nor to specific manifestations of translation universals in the noun phrase. These divergences can be explained by purely linguistic factors, such as fixed expressions (3.3.1.) and semantic differences in the referential force of the demonstrative determiner (3.3.2.).

\subsubsection{Fixed expressions}

The examples below illustrate lexical differences between French and Dutch involving the demonstrative determiner:

For instance, the Dutch time phrase in die tijd uses a demonstrative determiner, whereas the French translation à l'époque uses a definite article, although à cette époque-là also exists. In (28), the phrases à l'époque and in die tijd (just as indertijd = in de tijd van toen) are fixed expressions referring to a vague time period in the past. A modifier can be added after à l'époque, which is then no longer a fixed expression and indicates a specific point in time. In Dutch, a modifier can also be added after in de tijd, but not after in die tijd. 
(28) Par ailleurs, elle était, à l'époque, la représentante de la Belgique à l'Assemblée générale des Nations unies.

In die tijd was zij lid van de Belgische delegatie bij de Algemene Vergadering van de VN.

In example (29), à l'heure actuelle, another time expression, has been translated by op dit moment in the target text, which is not a simple case of implicitation of the adjective actuelle involving a demonstrative shift, but reflects a lexical difference between French and Dutch. First of all, à l'heure actuelle is a fixed expression mostly translated by a demonstrative determiner and without an adjective in Dutch (op dit moment). Alternatively, it can be translated as op het huidige moment or by op dit huidige moment. In contrast, the construction à cette heure actuelle does not exist in French. On the other hand, op dit (huidige) moment can be literally translated en ce moment (même), which has the same meaning as à l'heure actuelle. Finally, the phrase à cette heure, meaning nowadays as in (29), is not considered standard French, although it is used in Walloon, ${ }^{3}$ in Louisiana Creole (Neumann-Holzschuh 1985), in Acadian French (Butler 1995) and in Quebec French ${ }^{4}$ with variant spellings (asteur, asteure, asteûre, astheure, à c't'heure).

(29) Pierre Rion: «À l'heure actuelle, je suis administrateur de 17 sociétés, soit au travers de mon activité de business angel soit comme administrateur indépendant.» Pierre Rion: "Op dit moment ben ik bestuurder van 17 vennootschappen, hetzij via mijn activiteit van business angel hetzij als onafhankelijk bestuurder."

Lexical differences involving demonstrative shifting also occur in phoric uses of the demonstrative determiner. For instance, in example (30), the fixed expression de klus klaren (22 500 Google hits) ${ }^{5}$ referring to the responsibilities of the national health service in the preceding text, is more frequently used than deze klus klaren (2 970 Google hits), whereas in French mener cette mission à bien (2950 Google hits) is more frequent than mener la mission à bien (265 Google hits). Note, however, that in this example the demonstrative determiner is possible in both languages.

(30) Het Rijksinstituut voor Ziekte- en Invaliditeitsverzekering (RIZIV) beheert een sleutelsector van de sociale zekerheid: de verzekering voor geneeskundige verzorging en de daaraan gekoppelde uitkeringen. Dat is geen eenvoudige opgave, maar het RIZIV weet de klus toch te klaren, jaar na jaar. Ook in 2006 zorgde het RIZIV voor een kwaliteitsvolle dienstverlening, zo blijkt uit het pas verschenen jaarverslag. L'Institut national d'assurance maladie-invalidité (INAMI) gère un secteur clé de la sécurité sociale: l'assurance soins de santé et les indemnités qui y sont liées. La tâche est rude, mais l'INAMI a su mener cette mission à bien, année après année. En 2006 aussi, l'INAMI a proposé un service de qualité, ce que confirme le récent rapport annuel.

\subsubsection{Semantic differences}

There are also important semantic differences in the referential force of the demonstrative determiner in French and in Dutch:

In its recognitial use, ${ }^{6}$ (Diessel 1999; Gary-Prieur 1998; Himmelmann 1996; Jonasson 1998; Kleiber 2005; Kleiber and Sock 2006), the French demonstrative determiner (source language) is translated by the definite article in Dutch in $31.30 \%$ of cases. In all these cases, it is only possible to use a demonstrative determiner in French, whereas in Dutch both the demonstrative determiner and the definite article, 
combined with generalizing elements (such as on, toujours, en principe), are possible. In (31), for instance, the demonstrative determiner is not excluded in Dutch, but its strong referential (i.e., situational and/or textual) force makes it less suitable for recognitial use. Hence, the definite article is more appropriate. In French, in contrast, the demonstrative determiner is bleached (see e.g., De Mulder and Carlier 2006), making it appropriate for recognitial use. The definite article is excluded.

(31) Et toi? Viens-tu au rendez-vous parfois? Regretter ce baiser qu'on ne s'est pas donné?

En jij? Denk jij aan de ontmoeting wel eens? Met spijt om de kus die niet is gewisseld?

This fundamental semantic difference between French and Dutch also exists for some anaphoric uses (i.e., textual reference) of the demonstrative determiner. In the next example, the noun phrases cette collection and ces 956 pièces have been translated using the Dutch definite article in the target text (de verzameling and de 956 stukken). Again, the demonstrative determiner is not excluded in Dutch, but its strong spatio-temporal reference would seem to exceed the requirements of textual cohesion. On the other hand, in French, the textual recuperation in the form of a noun phrase with a definite article would be too weak.

(32) Une fois les collections mises au sec, le musée prend une nouvelle orientation en 1994 et se consacrera pendant quatre années au verre et à la céramique. Bien que témoignant du goût d'un seul homme, cette collection apparaît comme un des rares fonds publics représentatifs de la création en France et en Europe des années 1950 à 1980. Presque tous les mouvements artistiques de l'après-guerre sont présents à travers ces 956 pièces (peintures, sculptures, assemblages, dessins, estampes).

Zodra de collectie op het droge was gebracht, wijdde het museum zich vanaf 1994 gedurende vier jaar aan glas- en keramiekwerken. Hoewel de verzameling door één individu werd bijeengebracht, behoort ze tot de zeldzame openbare collecties die representatief zijn voor de kunst tussen 1950 en 1980 in Frankrijk en Europa. Haast alle naoorlogse stromingen zijn vertegenwoordigd in de 956 stukken (schilderijen, beeldhouwwerken, assemblages, tekeningen, prenten).

This is also the case in the next example: both the Dutch definite article (de bekende Antwerpse advocaat) and the French demonstrative determiner (cet avocat bien connu à Anvers) have normal anaphoric force, whereas the Dutch demonstrative determiner (deze bekende Antwerpse advocaat) has very strong anaphoric force and ensures the effectiveness of the anaphoric process. The anaphoric force of the French definite article (l'avocat bien connu à Anvers), on the other hand, is too weak.

(33) Naast moeder en vrouw volgt ook oom Werner Lens de ontwikkeling van Lombardia op de voet. De bekende Antwerpse advocaat staat Indria bij met juridisch advies.

À côté de sa mère et de sa femme, l'oncle d'Alain, Werner Lens, suit aussi de près le développement de Lombardia. Cet avocat bien connu à Anvers l'assiste de ses conseils juridiques.

The semantic difference between French and Dutch with respect to the anaphoric use of the demonstrative also affects cleft and presentative sentences, as illustrated 
in examples (34) and (35). The cleft construction c'est (X) ce Y que ... has to be translated as het is die Y die / waarin / waardoor ... in Dutch, which demonstrates the bleaching of the demonstrative pronoun ce in c'est. A similar observation can be made with regard to presentative sentences: in the construction c'est $(X)$ ce Y que ..., the demonstrative pronoun ce in c'est is bleached and accepts a demonstrative determiner, whereas the demonstrative pronoun dat in dat is is too strong in Dutch and does not accept a demonstrative determiner ( ${ }^{*}$ dat is die $\mathrm{Y}$ die / waarin / waardoor...). In the latter construction, the definite article is used in Dutch (dat is de Y die / waarin / waardoor...).

(34) Thuis spraken we Fries en dat was de taal waarin mijn wereld als klein kind vorm kreeg.

À la maison, nous parlions frison, et c'est dans cette langue que mon univers a pris forme lorsque j'étais enfant.

(35) Beaucoup d'idéalistes, la tête dans les nuages, souffrent d'un mal tout aussi redoutable, incapables qu'ils sont de traduire dans la pratique leurs idéaux élevés. Seuls en sont capables les hommes et les femmes politiques - et ils sont plutôt rares - qui unissent en eux pragmatisme et idéal, conviction et tolérance. C'est ce paradoxe que j'ai toujours admiré le plus en la personne de Willy De Clercq.

Veel idealisten, het hoofd in de wolken, leiden aan een al even erge kwaal, omdat ze hun bevlogen idealen nooit in de praktijk kunnen omzetten. Dat kunnen uitsluitend politici, en die zijn relatief zeldzaam, die het pragmatische en het ideële niveau en een overtuigd en verdraagzaam profiel in zich verenigen. Dat is de paradox die ik in Willy De Clercq altijd het meest heb bewonderd.

Finally, some time phrases in rhematic position, expressing anteriority with respect to the moment of speech, such as ces derniers temps (36) and ces vingt dernières années (37), are always translated by a definite article in Dutch (de jongste tijd, de laatste twintig jaar) rather than by a demonstrative determiner. In contrast to the French demonstrative, the Dutch demonstrative has very strong referential force and hence does not accept a numeral or the adjective laatste in the same time phrase ( ${ }^{\star}$ deze laatste (twintig) jaar).

(36) Il ne s'agit pas d'un ouvrage politique, comme on a l'habitude d'en lire ces derniers temps.

Meer ook dan een politiek boek; een genre dat de jongste tijd trouwens welig tiert.

(37) Nous avons annoncé, sans nous tromper, les principales crises de ces vingt dernières années et nous n'avons pas tiré intempestivement la sonnette d'alarme, protégeant ainsi la banque et nos clients de manques à gagner certains.

Zo hebben wij de laatste twintig jaar feilloos de belangrijkste crisissen aangekondigd en hebben wij niet te onpas aan de alarmbel getrokken, waardoor we zowel de bank als onze cliënten wisten te beschermen tegen bepaalde winstdervingen.

\section{Conclusion}

The aim of this paper was to study the translation of the demonstrative determiner in French and Dutch in parallel corpora, in order to determine which types of translation shifts occur systematically and what the underlying mechanisms and semantic effects of this process are. Analysis based on a sub-corpus of the Dutch Parallel 
Corpus showed that translational shifts with respect to the French and Dutch demonstrative determiner occur at three different levels: at the level of the noun phrase, within the noun phrase and at the level of the determiner. Table 18 and table 19 give a detailed overview of these findings:

TABLE 18

Overview of translational shifts in the French SL corpus and the Dutch TL corpus

\begin{tabular}{|l|l|r|r|r|r|c|}
\hline \multicolumn{1}{|c|}{ French SL } & Dutch TL & Total & $\begin{array}{c}\text { Changes to } \\
\text { the entire } \\
\text { NP }\end{array}$ & $\begin{array}{c}\text { Changes } \\
\text { within the } \\
\text { NP }\end{array}$ & $\begin{array}{c}\text { Changes at the } \\
\text { determiner } \\
\text { level }\end{array}$ & $\begin{array}{c}\text { No } \\
\text { changes }\end{array}$ \\
\hline Demonstrative & Demonstrative & $236(100 \%)$ & $28(11.86 \%)$ & $13(5.51 \%)$ & $/$ & $195(82.63 \%)$ \\
\hline Demonstrative & Other structure & $111(100 \%)$ & $67(60.36 \%)$ & $16(14.41 \%)$ & $28(25.23 \%)$ & $/$ \\
\hline Demonstrative & Definite article & $96(100 \%)$ & $17(17.71 \%)$ & $27(28.13 \%)$ & $52(54.17 \%)$ & $/$ \\
\hline Other structure & Demonstrative & $73(100 \%)$ & $50(67.49 \%)$ & $4(5.48 \%)$ & $19(26.03 \%)$ & $/$ \\
\hline Definite article & Demonstrative & $21(100 \%)$ & $3(14.29 \%)$ & $2(9.52 \%)$ & $16(76.19 \%)$ & $/$ \\
\hline
\end{tabular}

TABLE 19

Overview of translational shifts in the Dutch SL corpus and the French TL corpus

\begin{tabular}{|l|l|r|r|r|r|c|}
\hline \multicolumn{1}{|c|}{ Dutch SL } & French TL & Total & $\begin{array}{c}\text { Changes to } \\
\text { the entire } \\
\text { NP }\end{array}$ & $\begin{array}{c}\text { Changes } \\
\text { within the } \\
\text { NP }\end{array}$ & $\begin{array}{c}\text { Changes at the } \\
\text { determiner } \\
\text { level }\end{array}$ & $\begin{array}{c}\text { No } \\
\text { changes }\end{array}$ \\
\hline Demonstrative & Demonstrative & $294(100 \%)$ & $32(10.88 \%)$ & $11(3.74 \%)$ & $/$ & $251(85.37 \%)$ \\
\hline Demonstrative & Other structure & $63(100 \%)$ & $45(71.43 \%)$ & $0(0 \%)$ & $18(28.57 \%)$ & $/$ \\
\hline Demonstrative & Definite article & $42(100 \%)$ & $6(14.29 \%)$ & $9(21.43 \%)$ & $27(64.29 \%)$ & $/$ \\
\hline Other structure & Demonstrative & $98(100 \%)$ & $66(67.35 \%)$ & $2(2.04 \%)$ & $30(30.61 \%)$ & $/$ \\
\hline Definite article & Demonstrative & $60(100 \%)$ & $4(6.67 \%)$ & $12(20 \%)$ & $44(73.33 \%)$ & $/$ \\
\hline
\end{tabular}

First, the analysis suggests that - with respect to the French and Dutch demonstrative - translator preference is mainly involved in instances of omission, addition or reformulation of the noun phrase $30.73 \%$ of all instances in the French SL - Dutch TL corpus, $83.03 \%$ of these instances involving demonstrative shifting, and $27.47 \%$ of all the cases in the Dutch SL - French TL corpus, $79.08 \%$ of these cases involving demonstrative shifting). These instances illustrate the inherent variability of the translation process rather than a divergence between the Dutch and French determiner system, as these noun phrases containing a French or Dutch demonstrative determiner are clearly not 'untranslatable' and could easily be expressed differently.

Second, in order to verify whether specific manifestations of translation universals within the noun phrase could explain other translation shifts with respect to the demonstrative, syntagmatic and paradigmatic changes in the noun phrase were examined $(11.55 \%$ of all instances in the French SL - Dutch TL corpus, $77.78 \%$ of these cases involving demonstrative shifting, and $6.10 \%$ of all instances in the Dutch SL - French TL corpus, $67.65 \%$ of these cases involving demonstrative shifting). Findings show that the interaction between the demonstrative determiner and the definite article is strongly dependent on the type specification of the noun and its modifiers. As was illustrated above, syntagmatic and paradigmatic explicitation of the noun phrase in the target text involving different type specifications of the noun and its modifiers may cause a demonstrative determiner in the source text to be 
translated by a definite article in the target text. Conversely, syntagmatic and paradigmatic implicitation of the noun phrase in the target text may cause a definite article in the source text to be translated by a demonstrative determiner in the target text.

Third, analysis of instances of complete NP - NP correspondence involving only a determiner shift (21.42\% of all instances in the French SL - Dutch TL corpus, and $21.36 \%$ of all instances in the Dutch SL - French TL corpus) revealed structural divergences between the French and Dutch demonstrative determiner systems. More precisely, French and Dutch were found to use different fixed expressions at the level of the temporal (e.g., à l'époque vs in die tijd, à l'heure actuelle vs op dit (huidige) moment) and the textual (e.g., mener cette mission à bien vs de klus klaren) uses of the demonstrative determiner in French and Dutch. The findings also revealed considerable semantic differences in the referential force of the demonstrative determiner in French and Dutch. The French demonstrative is more bleached than the Dutch demonstrative, and is more frequently used in some specific contexts where Dutch would prefer the definite article (e.g., recognitial use, indirect anaphors, specific temporal uses).

Finally, this paper tries to demonstrate the usefulness of a detailed parallel corpus study, which clearly distinguishes between changes at different levels, in accounting for divergent translations of the demonstrative determiner in different languages. To this end, several types of explanation, drawn from various fields (such as translation studies and contrastive linguistics), must be considered.

\section{NOTES}

1. The structure of all the examples in this paper is similar: first the source text is given, followed by the translation in the target text.

2. I.e. demonstrative pronoun (source language) - demonstrative determiner (target language).

3. http://wa.wikipedia.org/wiki/Mot\%C3\%AE:asteure>, visited on 13 May, 2010.

4. http://www.laparlure.com/terme/asteure/, visited on 13 May, 2010.

5. Date retrieved: 13 May, 2010.

6. "In the recognitial use, the intended referent is to be identified via specific, shared knowledge rather than through situational clues or reference to preceding segments of the ongoing discourse." (Himmelmann 1996: 230)

\section{REFERENCES}

BAKER, Mona (1993): Corpus linguistics and translation studies: implications and applications. In: Mona Baker, Francis Gill and Elena Tognini-Bonelli, eds. Text and Technology. Amsterdam and Philadelphia: Benjamins, 233-252.

Blum-Kulka, Shoshana (1986): Shifts of Cohesion and Coherence in Translation. In: Juliana House and Soshana Blum-Kulka, eds. Interlingual and Intercultural Communication: Discourse and Cognition in Translation and Second Language Acquisition Studies. Tübingen: Nar, 17-37.

Butler, Gary (1995): Histoire et traditions orales des Franco-Acadiens de Terre-Neuve. Sillery: Septentrion.

Chesterman, Andrew (2001): Hypotheses about translation universals. In: Gide Hansen, Kirsten Malmkjær and Daniel Gile, eds. Claims, Changes and Challenges in Translation Studies. Amsterdam: John Benjamins, 1-13.

De Mulder, Walter and Carlier, Anne (2006): Du démonstratif à l'article défini: le cas de ce en français moderne. Langue française. 152:96-113. 
Diessel, Holger (1999): Demonstratives: form, function and grammaticalization. Amsterdam and Philadelphia: John Benjamins.

Gary-Prieur, Marie-Noëlle (1998): La dimension cataphorique du démonstratif. Étude de constructions à relative. Langue française. 120:44-50.

Goethals, Patrick (2007): Corpus-Driven Hypothesis Generation in Translation Studies, Contrastive Linguistics and Text Linguistics: A Case Study of Demonstratives in Spanish and Dutch Parallel Texts. Belgian Journal of Linguistics. 21:87-103.

Himmelmann, Nikolaus (1996): Demonstratives in Narrative Discourse: A Taxonomy of Universal Uses. In: Barbara Fox, ed. Studies in Anaphora. Amsterdam and Philadelphia: John Benjamins, 205-254.

JonAsson, Kerstin (1998): Le déterminant démonstratif: un marqueur de quoi? Travaux de linguistique. 36:59-70.

Klaudy, Kinga (1993): On explicitation hypothesis. In: Kinga Klaudy and Janos KoHN, eds. Transferre necesse est... Current Issues of Translation Theory. Szombathely: Daniel Berzsenyi College, 69-77.

Kleiber, Georges (2005): Des démonstratifs bien énigmatiques: les démonstratifs cataphoriques génériques. In: Carmen Dobrovie-Sorin, ed. Noms nus et généricité. Saint-Denis: Presses Universitaires de Vincennes, 65-95.

Kleiber, Georges and Sock, Rudolph (2006): Ces $+N+$ relative: Sémantique et prosodie. Lingvisticae Investigationes. 29(2):251-273.

LANGACKer, Ronald Wayne (1991): Foundations of Cognitive Grammar. II. Descriptive Application. Stanford: Standford University Press.

Neumann-Holzschun, Ingrid (1985): Le créole de Breaux Bridge, Louisiane: Étude morphosyntaxique, textes, vocabulaire. Hamburg: Helmut Buske Verlag.

Paulussen, Hans (1999): A corpus-based contrastive analysis of English "on/up," Dutch "op" and French "sur" within a cognitive framework. Doctoral thesis, unpublished. Ghent: Ghent University.

Paulussen, Hans, Macken, Lieve, Trushrina, Julia, et al. (2006): Dutch Parallel Corpus: a multifunctional and multilingual corpus. Cahiers de l'Institut de Linguistique de Louvain. 32(1-4):295-312.

Pym, Anthony (2005): Explaining explicitation. In: Krisztina Karoly, ed. New Trends in Translation Studies. In Honour of Kinga Klaudy. Visited 16 May 2011, <http://usuaris.tinet.cat/ apym/on-line/translation/explicitation_web.pdf>.

Toury, Gideon (2001): Probabilistic explanations in translation studies. In: Gide Hansen, Kirsten MalmkjÆr and Daniel Gile, eds. Claims, Changes and Challenges in Translation Studies. Amsterdam and Philadelphia: John Benjamins, 15-25.

Trushrina, Julia, Macken, Lieve and Paulussen, Hans (2008): Sentence alignment in DPC: maximizing precision, minimizing human effort. Proceedings of the $6^{\text {th }}$ Language Resources and Evaluation Conference (LREC 2008). (Marrakech, Morocco, 28-30 May 2008).

VANDERBAuWhede, Gudrun (2007): La détermination nominale en français et en néerlandais: le cas des démonstratifs. Bilan critique, étude de corpus, développement d'une unité didactique. Master thesis, unpublished. Leuven: Katholieke Universiteit Leuven.

VANDERBAuWhede, Gudrun (to appear): Les emplois référentiels du SN démonstratif en français et en néerlandais: pas du pareil au même. Journal of French Language Studies.

WhitTaker, Sunniva (2004): Étude contrastive des syntagmes nominaux démonstratifs dans des textes traduits du français en norvégien et des textes sources norvégiens: stratégie de traduction ou translationese? Forum, international journal of interpretation and translation. 2(2):221-239. 